\title{
The Effect of the Amylose Contents on the Rheological Properties of Rice Flour Pastes
}

\author{
Isamu KanEDA ${ }^{\dagger}$, Hiroki TANAKA, and Tomohito IwASAKI \\ Department of Food Science and Wellness, College of Agriculture, Food, and Environment Science, \\ Rakuno Gakuen University, Ebetsu-shi, Hokkaido Japan
}

\begin{abstract}
The high amylose rice KITAMIZUHO developed in Hokkaido is expected to be applied to various foods because its rice flour paste shows high viscoelasticity. In order to systematically investigate the relationship between this characteristic rheological property and amylose content, the rheological properties of various rice flour pastes. For the rheological properties, the frequency dependence of the complex modulus of each rice flour paste was analyzed by a weak-gel model (WGM). We can obtain the coordination number (z) which shows the spatial density of the swollen starchy endosperm and starch granules in the rice flour paste using the model. KITAMIZUHO rice flour paste showed the higher $\mathrm{z}$ values than the middle and low amylose contents rice flours. It was expected that the higher the amylose content of rice starch, the larger the size of swollen starchy endosperm and starch granules. On the other hand, the observation using scanning electron microscopy revealed that the size of swollen starch granules of KITAMIZUHO was larger than the other rice flour paste. These results suggest that the characteristic rheological properties of the KITAMIZUHO rice flour paste, is due to the relatively large size of its swollen starchy endosperm and starch granules.
\end{abstract}

Key Words: Rice flour / Starch granules / Amylose / Weak-gel / SEM

\section{米粉ペーストのレオロジー特性に対するアミロース含量の影響}

\section{金田 勇”，田中 宏樹，岩崎 智仁}

(原稿受理 : 2020 年 3 月 5 日)

\section{1. 緒 言}

我が国では年々米の消費量が減少しておりそれに伴い, 水 田や米の生産量が減少している。 そのため米の消費量を増や すため新たな米の用途開発・拡大が進められている。しかし ながらコメの消費量は漸減傾向にあり, その要因の一つとし てコメを粒食する需要が減り, 一方でパン食が増加している ことが挙げられる，そこでコメの消費量を増加させる一つの 方策として米粉への加工に適した高アミロース米の開発が国 の施策の一つとして推進されてきた。

高アミロース米とはアミロース含有量が $25 \%$ 以上のもの を指さす. 高アミロース米は, 一般的な米よりも粘り気が少 なく硬い性質を持っているため通常の炊飯米としては不向き であり, フォー (米粉めん) や生春巻き（ライスペーパー）, リゾットやグリーンカレーなどに使われており，最近では製 パンにも応用されている品種もある。 キタミズホは 2003 年 に北海道農業研究センターにおいて耐冷性が優れている酒米 品種「初需」と耐倒伏性が強いインド型多収品種「夢十色」 との $\mathrm{F}_{1}$ に初零を花粉親として戻し交配し育成された寒地向

†酪農学園大学 農食環境学群 食と健康学類

T069-8501 北海道江別市文京台緑町582

E-mail : kaneda-i@rakuno.ac.jp, Tel : +81-11-388-4701
けの多収・高アミロース米であり, 米粉麺やクッキーへの加 工適正があるほか，その米粉ペース卜は特異的な粘弾性特性 を示すことがわかっている゙ が，その分子論的な原因は不明 である。

本研究で取り上げる米粉は米の胚乳の粉砕物であり, デン プン粒に加えて細胞壁の断片やたんぱく質等も含む粉体であ る.この米粉に加水して加熱したペーストは主に糊化して膨 潤したデンプン粒と上述の夾雑物が共存したコロイド分散体 として捉えることができる.デンプン水分散液を加熱処理し て得られるいわゆるデンプンペーストのレオロジー特性はデ ンプンの食品への応用において重要なパラメータの一つであ る.デンプンペーストのレオロジー特性は一般的にラピッ ド・ビスコ・アナライザー（RVA）による研究が蓄積されて きた2). RVA は水に懸濁させたデンプンを加熱しながらパド ルで攪拌し，そのトルクをモニターすることでサンプルの粘 度を算出する装置であり, 糊化温度等の情報を得ることがで きる。しかしながら糊化過程の過渡的な見かけ粘度を測定し ているにすぎないために得られる情報は少ない.

一方でデンプンの化学構造については生デンプンの状態の 構造に関しては莫大な情報が蓄積されており, 結晶性の高い アミロペクチンが形成するラメラ構造がアミロースを多く含 むとされているアモルファス領域に挟まれた多相構造が提唱 されており ${ }^{3,4)}$, その多相構造が基本構造単位としていわゆ 
るデンプン粒を形成しているとされている．しかしながら， これらの情報は生デンプンを解析した結果であり, 糊化した デンプンペーストに関する線形粘弾性特性や構造に関する研 究は極めて少ないのが現状である.

本研究は同一工程で製粉されたアミロース含量の異なる米 粉を用い, 最小限のせん断負荷により糊化された米粉ペース トのレオロジー特性と走査型電子顕微鏡観察によって高アミ ロース米の米粉であるキタミズホの特異的な力学特性発現の メカニズムを考察することを目的とした。

\section{2. 材料および方法}

\section{$2-1$ 材料}

米粉は農研機構北海道農業研究センターにおいて 2017 年 に収穫されたオボロツキ, ナナツボシおよびキタミズホの $90 \%$ 搗精した精白米を乾式小型製粉機（SATAKE SRG05A， $0.5 \mathrm{~mm}$ スクリーン）で製粉された米粉試料の提供を受け, それらをそのまま使用した。これらの試料の見かけのアミ ロース含量はヨウ素呈色比色法の変法で測定され ${ }^{1)}$, オボロ ツキは $15.3 \%$, ナナツボシは $19.7 \%$ およびキタミズホは $30.4 \%$ であった.

\section{2-2 電子レンジによる米粉ペーストの調製法}

それぞれの米粉を 6 12\% 含む米粉ペースト（糊液）を 廣瀬らの方法 ${ }^{5}$ を参考にして以下に述べる方法で調製した.

$50 \mathrm{ml}$ ビーカーに米粉と水の総量が $30 \mathrm{~g}$ になるように量り とりペンシルミキサーで 20 秒間撹找し米粉を分散させた.

これを電子レンジで $700 \mathrm{~W}, 10$ 秒間加熱し，ただちにペン シルミキサーで 20 秒間攪拌する。 この工程を 5 回繰り返し 行った. 工程の最終時点での試料温度は $85 \sim 90{ }^{\circ} \mathrm{C}$ に到達し ていることを確認した。 得られた米粉ペーストサンプルは $25^{\circ} \mathrm{C}, 1$ 時間静置したのちに測定に供した.

試料コードはオボロツキ, ナナツボシ, およびキタミズホ の米粉ペーストをそれぞれ $\mathrm{O}-\mathrm{x}, \mathrm{N}-\mathrm{x}$ ，および $\mathrm{K}-\mathrm{x}$ とした. ここでxはとそぞれの米粉の質量パーセント濃度 $(\mathrm{wt} \%)$ を 示す.

\section{2-3 レオロジー特性}

ひずみ制御型回転式レオメータ ARES（TA Instrument 社） を用いて定常流粘度のずり速度依存性および動的弾性率の周 波数依存性を温度 $25^{\circ} \mathrm{C}$ で測定した。測定治具は $25 \mathrm{~mm} ハ ゚$ ラレルプレート（gap $1.5 \mathrm{~mm}$ ）を用いた。測定条件は定常流 粘度測定においてはずり速度 $0.1 \sim 1001 / \mathrm{s}$, 動的弾性率測定 においては周波数範囲は $0.5 \sim 50 \mathrm{rad} / \mathrm{s}$, ひずみは 0.01 とした.

\section{2-4 走査型電子顕微鏡（SEM）による観察}

米粉はデシケータで十分に乾燥した後, SEM 用試料台に 貼り付けたカーボン両面テープ上に散布し, 白金蒸着して観 察試料を作成した，米粉ペースト試料は $12 \mathrm{wt} \%$ の米粉ペー ストを $50 \%$ エタノールで溶媒置換した後に, 液化イソペン タンで急速凍結した後に凍結乾燥した。凍結乾燥された試料 を小型ハンマーで割断し, その表面を白金蒸着して観察試料 を作成した。これらの観察試料を走査型電子顕微鏡 S-2460N 形（日立ハイテクノロジー）で付加電圧 $10 \mathrm{kV}$, の条件で観 察した。

\section{3. 結果及び考察}

\section{3-1 米粉ペーストの流動挙動}

Fig. 1 に-10, N-10, および O-10の粘度一ずり速度曲線 を示す。いずれの試料も指数則に従う流動軟化挙動を示した またN-10 と O-10 は測定したずり速度の範囲でほぼ同等の 粘度を示しているが，K-10のみが高かった，低ずり速度領 域においても流動曲線に平坦部が観察されないことから, こ れらの米粉ペーストは見かけの降伏応力を持つ擬塑性流動を 示すと考えられた. Fig. 1 に示したデータをずり応力ーずり 速度曲線としてプロットしたのが Fig. 2 である。図中の曲線 は非ニュートン流動を記述する経験式である HerschelBulkley 式（Eq. 1) で解析した結果を示す.

$$
\sigma=k \gamma^{n}+\sigma_{y}
$$

ここで $\sigma$ はずり応力, $\mathrm{k}$ は粘性係数, $\gamma$ はずり速度, $\mathrm{n}$ は Herschel-Bulkley 係数, $\sigma_{\mathrm{y}}$ は見かけの降伏応力である. Table I に解析結果をまとめて示す.

Fig. 1 にも示されているように粘性係数はK-10が他の 2 試料に比べて極めて高かった。この粘性係数の值は $\mathrm{n}$ の值に 依存するが, $\mathrm{n}$ はいずれの試料においても 0.4 近傍の值であ り，流動軟化挙動は質的にはほぼ同等と考えることができる。 注目すべきは見かけの降伏応力の值でありこれはいずれの試 料においても有限な值を示し, かつ粘性係数の大きさと連動 している．有限な見かけの降伏応力を観察したということは これらの米粉ペースト内にある臨界值未満の歪に対して内部 応力を発生させる構造が形成されていることが予想される。 そこでこれらの米粉ペーストの動的弾性率の周波数依存性を 解析することを試みた.

Table I The Herschel Bulkely parameters for 3 types rice flour paste.

\begin{tabular}{cccc}
\hline & $\mathrm{O}-10$ & $\mathrm{~N}-10$ & $\mathrm{~K}-10$ \\
\hline$k\left[\mathrm{~Pa} \cdot \mathrm{s}^{\mathrm{n}}\right]$ & $47.4 \pm 2.05$ & $65.2 \pm 8.92$ & $182 \pm 10.2$ \\
$\sigma_{\mathrm{y}}[\mathrm{Pa}]$ & $8.40 \pm 2.63$ & $8.42 \pm 3.65$ & $18.1 \pm 14.7$ \\
$\mathrm{n}[-]$ & $0.47 \pm 0.01$ & $0.41 \pm 0.02$ & $0.35+0.03$ \\
\hline
\end{tabular}

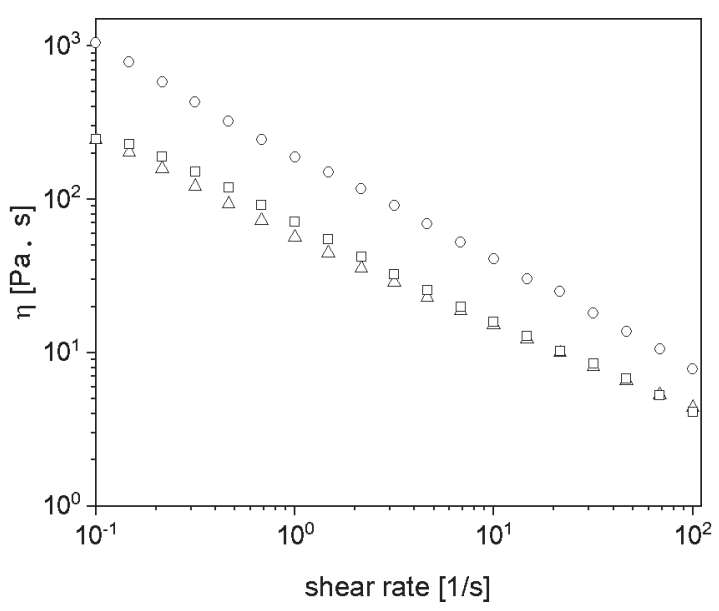

Fig. 1 The shear rate dependence on the apparent viscosity for the 3 types of rice flour paste. The open circles, squares, and triangles denote the results of K-10, N-10, and O-10, respectively. 


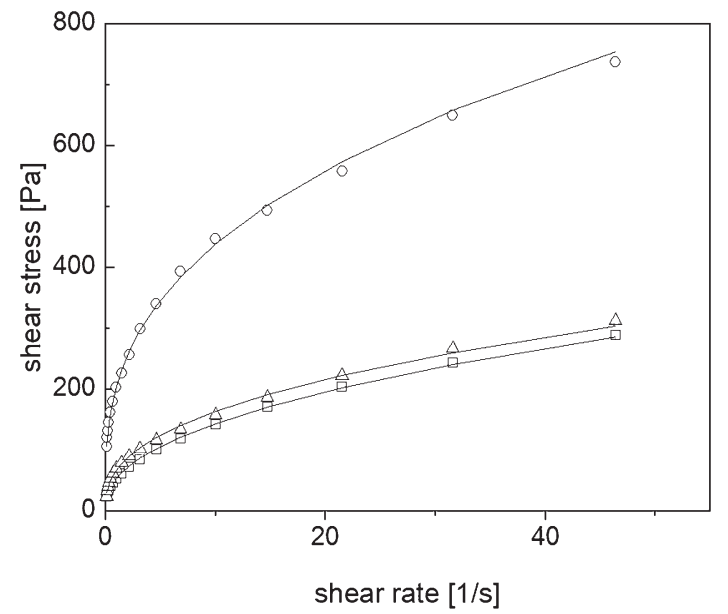

Fig. 2 The shear rate dependence on the shear stress for the 3 types of rice flour paste. The open circles, squares, and triangles denote the results of $\mathrm{K}-10, \mathrm{~N}-10$, and $\mathrm{O}-10$, respectively. The lines denote the best fit results of the analysis using Eq. 1 for each sample.

\section{3-2 Weak-gel model による米粉ペーストのカ学スペクト ルの解析}

すでに各種米粉ペーストの粘度ーずり速度曲線が指数則に 従うパターンを示すことを述べた，粘度一ずり速度曲線のみ ならず応力緩和曲線や動的弾性率の周波数依存性が指数則に 従うようなケースはいわゆる複雑流体において多く観察され ている. Bohlin ${ }^{6}$ は液晶の応力緩和曲線が指数則に従うこと を観察し，この指数と系内の構造を関連付ける理論を提唱し た。この理論は系内に仮想的な流動単位を考える。濃厚な流 動単位の分散体に外力が加わった際に, この流動単位は周辺 の流動単位との空間的な配置によっては協同的な変形・流動 が生じると考えられる。その協同的再配列に要するエネル ギーを計算することで流動単位の空間的な配置状況を定量化

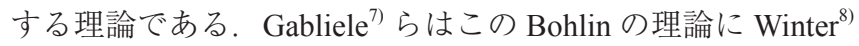
らの臨界ゲルのアイデアを取り入れ, 複雑流体の構造に関す る情報をレオロジー測定データより推定する weak-gel model （WGM）を提唱した.

WGM では複素弾性率と周波数を下式のように記述できる としている.

$$
G^{*}=A_{f} \omega^{1 / z}
$$

ここで $\mathrm{G}^{*}$ は複素弾性率, $\mathrm{A}_{\mathrm{f}}$ はゲル強度, $\omega$ は周波数, $\mathrm{z}$ は配 位数を表す。この配位数 $\mathrm{z}$ が上述の仮想的な流動単位の空間 的な充填度を示すパラメータである. すなわち $\mathrm{z}$ の值が大き いほど実在の系においてはコロイド粒子が密に充填している ことを示す。一方で $\mathrm{A}_{\mathrm{f}}$ はいわば系のコンシステンシーを定 量的に示すものである. WGM は食品のレオロジー特性の解 析に幅広く活用されており ${ }^{9-13)}$, 我々は乳化系食品であるマ ヨネーズの内油相比の異なるモデルマヨネーズの内油相比と 配位数が良い相関を示すことを明らかにしている ${ }^{14,15)}$.

Fig. 3 に-10, N-10 および K-10の複素弾性率の周波数依 存性の典型的な結果を示す。 O-10 および N-10 は測定周波数 範囲でそれぞれの貯蔵弾性率が損失弾性率を上回り，かつ指 数則に従っている.K-10についても貯蔵弾性率が損失弾性 率を大きく上回り, 貯蔵弾性率のスケーリング指数（両対数 プロットの傾き）は他の二つの試料に比べて小さく見える。

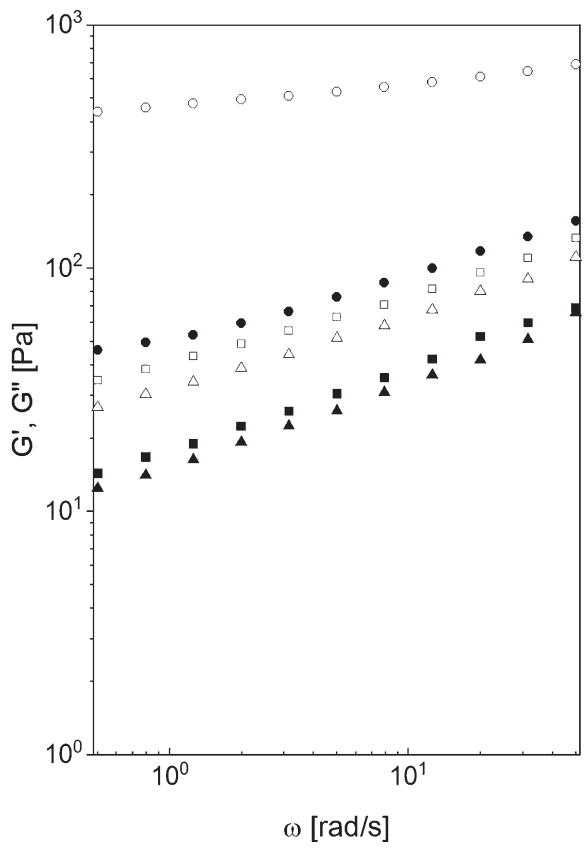

Fig. 3 The frequency dependence on the dynamic moduli for the 3 types of rice flour paste. The open and closed symbols denote storage modulus and loss modulus, respectively. The circles, squares, and triangles denote the results of $\mathrm{K}-10, \mathrm{~N}-10$, and $\mathrm{O}-10$, respectively.

米粉ペーストのこのような力学スペクトルはすでに報告があ $り^{16)}$ 糊化したデンプンペーストに関しては一般的な特性で あると考えられる。アミロース含量の異なるこれらの米粉 ペーストはいずれもその動的弾性率は周波数に対してスケー リングしており，WGMでの解析が有効であると考えられた。

\section{3-3 アミロース含量の異なる米粉ペーストのレオロジー特 性の米粉濃度依存性}

米粉ペーストの力学スペクトルをWGM で解析し、その パラメータの米粉濃度依存性について考察した。アミロース 含量の最も低いオボロツキ（O-6〜 O-12）ではいずれの濃度 のサンプルも複素弾性率は周波数に対してスケールしており, また米粉濃度に応じて複素弾性率の值が上昇していることが 見て取れた (Fig. 4).ナナツボシのスケーリング挙動はオボ ロツキと同様であるが、オボロツキと異なるのは N-10 と N-12 の間で大きく複素弾性率の值が上昇している点である (Fig. 5). 最後にFig. 6 に最もアミロース含量が高いキタミ ズホの結果を示すが、いずれの濃度においても他の二つの米 粉に比べて複素弾性率の值が高く、スケーリング指数も小さ いように見える.

これらの米粉間の複素弾性率の周波数依存性を定量的に比 較するために Fig. 4〜6のデー夕を（Eq. 2）を用いて解析し， $\mathrm{WGM}$ パラメータ, すなわち配位数 $\mathrm{z}$ とゲル強度 $\mathrm{A}_{\mathrm{f}}$ とを求 めた。

6〜8\%の試料においてはキタミズホが 6 程度オボロツキ およびナナツボシは 4 程度というようにアミロース含量によ り z の值が異なるものの濃度依存性は見られないが, キ夕ミ ズホについては 8\% からナナツボシについては $10 \%$ を境に 大きく上昇した（Fig. 7)。上述のと打り配位数 $\mathrm{z}$ は仮想的な 流動単位の空間的充填度を示すパラメータであるが，米粉 ペーストにおいては膨潤した肧乳およびデンプン粒といった コロイド粒子の空間分布に対応していると考えられる。 キ夕 
ミズホやナナツボシで観察されたある濃度を境にしての急激 な上昇は colloid jamming のような現象が起きていることを 示唆していると考えられる。 ゲル強度 $\mathrm{A}_{\mathrm{f}}$ の濃度依存性も $\mathrm{z}$ の濃度依存性と同様な傾向を示している, すなわち、キタミ ズホでは $8 \%$, ナナツボシでは $10 \%$ を境にして上昇してい る (Fig. 8). 米粉ペーストに含まれているコロイド粒子の体 積分率がある臨界点を超えることでjamming 転移のような ことが起これば, 内部応力を発生させる構造が成長してコン システンシーが上昇するという現象は容易に理解することが できる。一方でアミロース含量の最も少ないオボロツキにつ いては検討した濃度範囲ではコンシステンシーの急激な上昇, すなわち米粉ペースト中のコロイド粒子の充填状態の転移は 見られなかった。

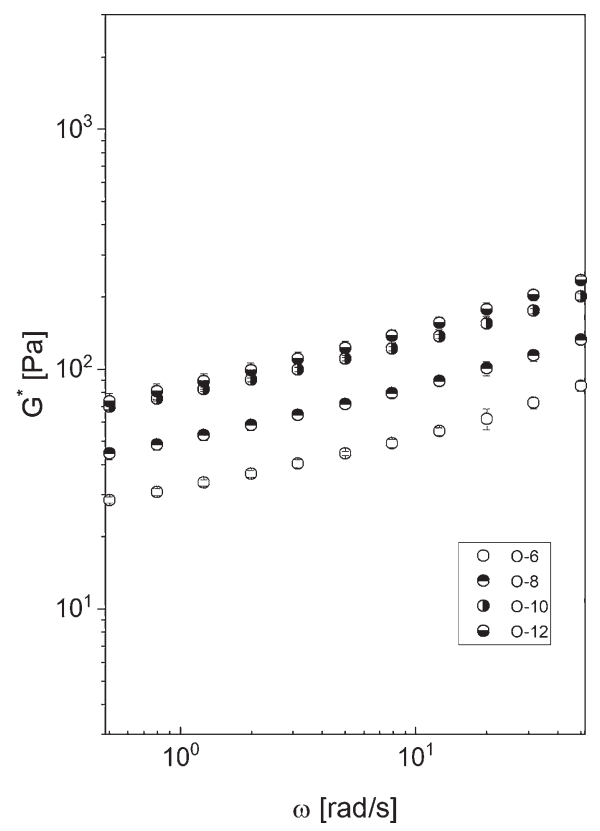

Fig. 4 The frequency dependence on the complex modulus for the various concentration OBOROTSUKI rice flour paste.

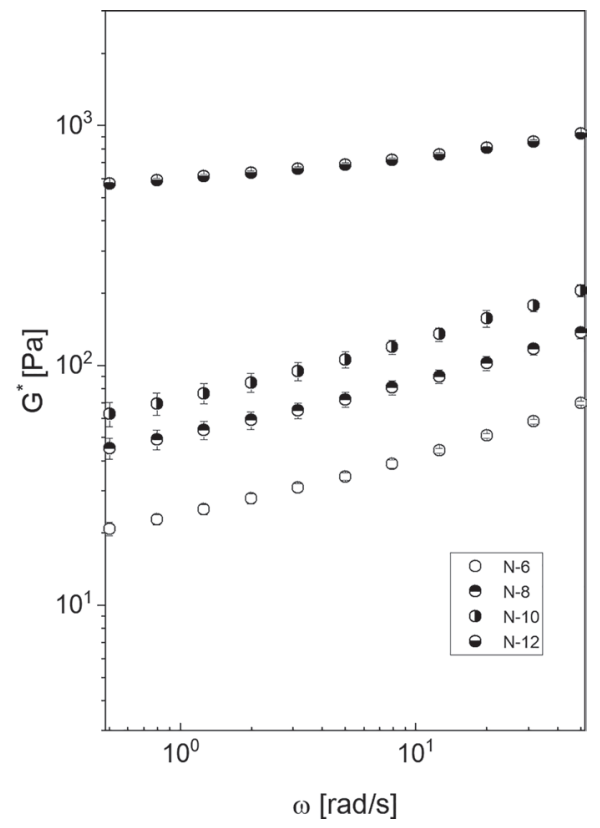

Fig. 5 The frequency dependence on the complex modulus for the various concentration NANATSUBOSHI rice flour paste.

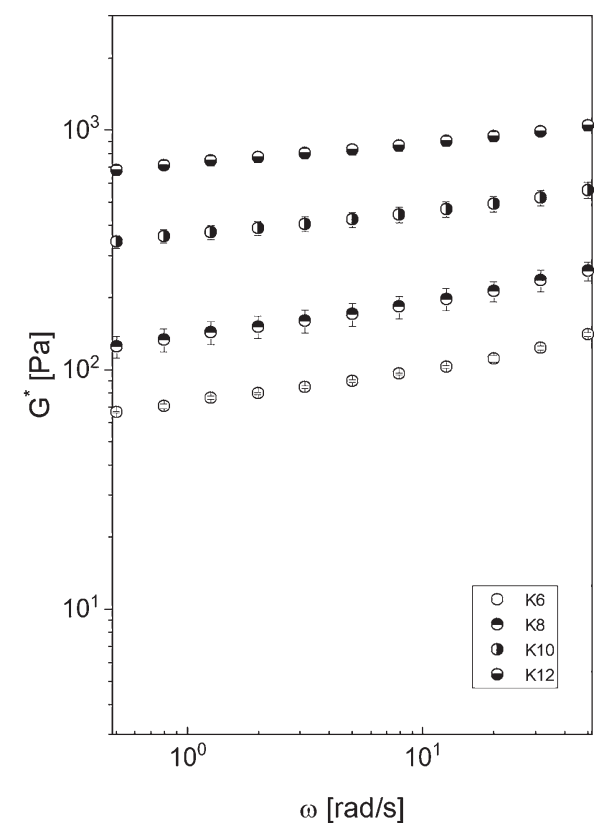

Fig. 6 The frequency dependence on the complex modulus for the various concentration KITAMIZUHO rice flour paste.

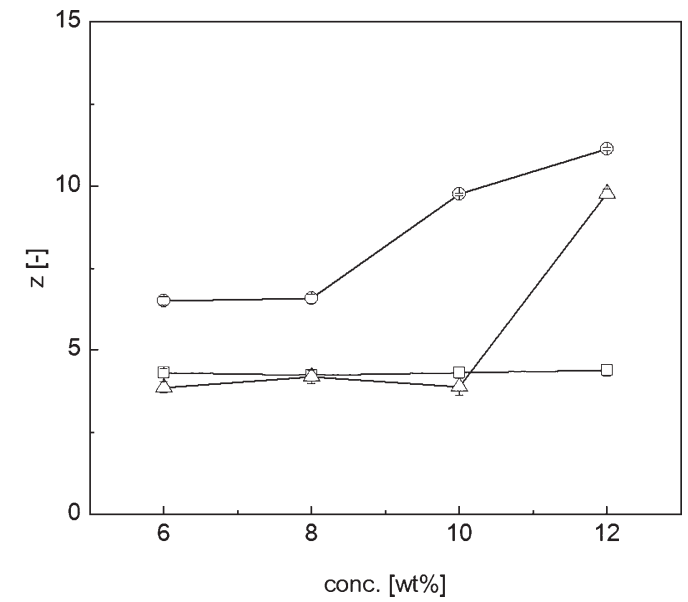

Fig. 7 The rice flour concentration dependence of the coordination number ( $\mathrm{z})$ which were analyzed using Eq.2. The open circles, squares, and triangles denote the results of KITAMIZUHO, NANATSUBOSHI, and OBOROTSUKI, respectively.

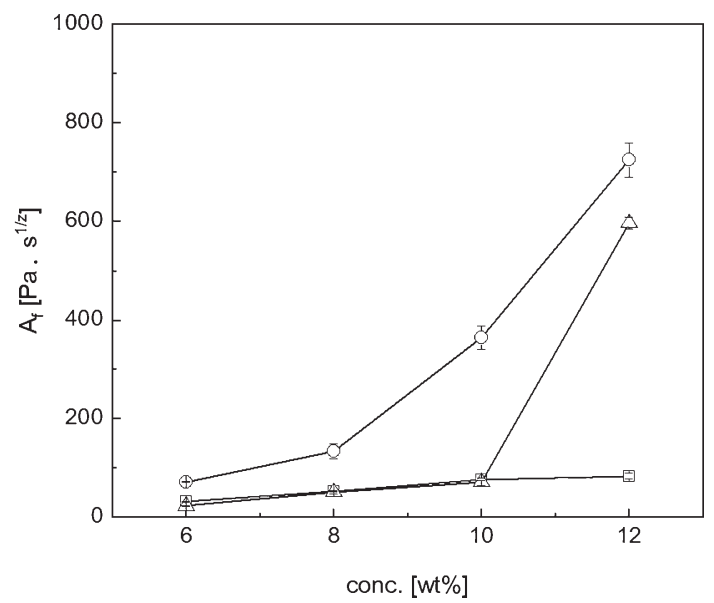

Fig. 8 The rice flour concentration dependence of the gel strength $\left(A_{f}\right)$ which were analyzed using Eq.2. The open circles, squares, and triangles denote the results of KITAMIZUHO, NANATSUBOSHI, and OBOROTSUKI, respectively. 
WGM パラメータから定量的に評価された三種類の米粉 ペースト中の膨潤したデンプン粒の空間的分布の違いの原因 はそれぞれの米粉中のデンプン粒の形態やサイズが異なって いるという可能性が考えられる。 そこで米粉ペーストの微細 構造を走査型電子顕微鏡で観察した.

\section{3-4 走査型電子顕微鏡（SEM）による米粉および米粉 ペースト微細構造の観察}

Fig. 9 に 3 種の米粉の SEM 画像を示した.いずれの試料 も数 $\mu \mathrm{m}$ 〜数 $10 \mu \mathrm{m}$ の粒子が観察された。米粉は肧乳を機械 的に磨砕して製粉したものであり，そこにはデンプン粒に加 えて細胞壁やたんぱく質が含まれていると考えられる。

Fig. 9 を注意深く観察するといずれの試料においても数 $10 \mu \mathrm{m}$ の比較的大きな粒子の表面には米デンプンに特徵的な 多角形のデンプン粒が集合している様子が観察される. 米の デンプン粒は品種あるいは育成条件によってそのサイズ・形 態が異なるということはすでに報告されており, 生デンプン の状態の SEM 観察ではそのサイズは 2〜 7 $\mu \mathrm{m}$ の範囲に及ぶ とされている ${ }^{18,19)}$. したがって米粉の状態ではデンプン粒が ばらばらに分散しているわけではなく, 肧乳中に充填した状 態で存在していることがわかった。一方で，米粉の粒度分布 や損傷デンプン量は製粉工程に大きく依存するとの報告があ るが ${ }^{17)}$, 本研究で用いた米粉はすべて同一の機器を用いて製 粉し， $0.5 \mathrm{~mm}$ メシュの篩で分級されているために Fig. 9 に示されたように品種による（アミロース含量による）粒度 分布の大きな違いはSEM 画像からは認められなかった。 ま

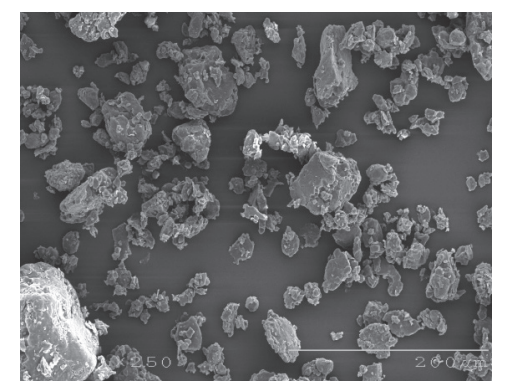

\section{a}
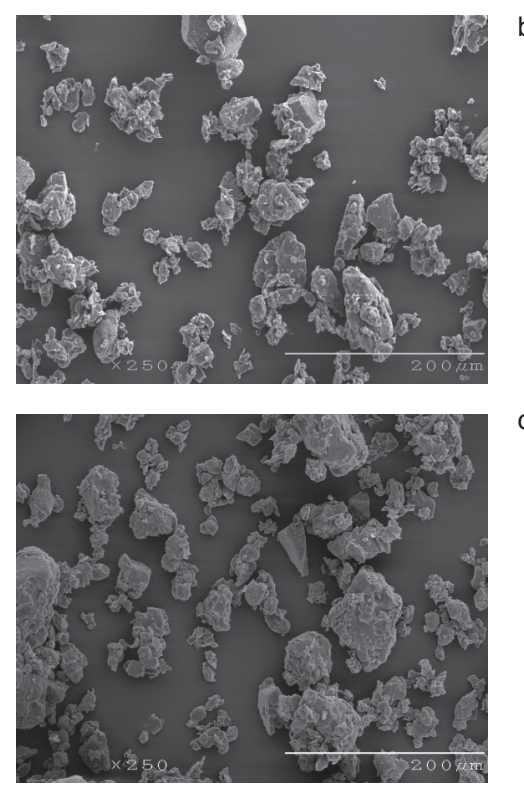

Fig. 9 The scanning electron microscope images of rice flour powders; OBOROTSUKI (a), NANATSUBOSHI (b), and KITAMIZUHO (c). The scale bar indicates $200 \mu \mathrm{m}(\times 250)$.
た本研究で使用した試料の損傷デンプン量は測定していない ため, SEM 画像からは損傷デンプンについて言及すること はできない.

一方で水を多く含んだ米粉ペーストのような試料を凍結乾 燥して電顕観察試料を調製する場合には, 試料内に極力水結 晶を成長させないような工夫が必要である。エ夕ノールは氷 結晶成長を抑制する効果があるので米粉ペーストを $50 \%$ 工 タノール水溶液で溶媒置換したのちに急速凍結して観察標本 を作製した。 Fig. 10aは O-12，bはN-12 および c は K-12の SEM 観察画像である。アミロース含量が最も低く，6〜12\% の濃度範囲で配位数 $\mathrm{z}$ の值に大きな変化が見られなかった O-12（a）は数 $\mu \mathrm{m}$ の多角形デンプン粒の特徵を示す粒子状 の構造が観察された. Fig. 9a の米粉の観察像と比べるとデ ンプン粒が充填した肧乳から糊化処理によってデンプン粒が ばらばらに分散したと考えられる。一方で N-12（b）は多角 形の粒子は見てとれるものの, 粒子の境目が不明瞭になって おり，K-12（c）においては大きな粒子がお互いに変形しな がら密に充填している様子が観察される。これらの試料は米 粉濃度 $12 \%$ であり, Fig. 7 に示した配位数 $\mathrm{z}$ の值と合わせ て考えてみると O-12 は $\mathrm{z}=4$ 程度である一方で N-12 および $\mathrm{K}-12$ は $\mathrm{z}=10$ 程度で WGM によるレオロジーデータから得 られた構造的情報である配位数からもこの SEM 観察の結果 を支持する結果となっている.

\section{3-5 アミロース含量とレオロジー特性の関連}

芦田ら ${ }^{1)}$ が報告している通りキタミズホの米粉は低濃度で

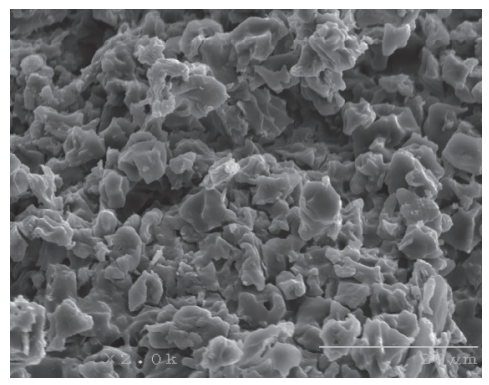

a
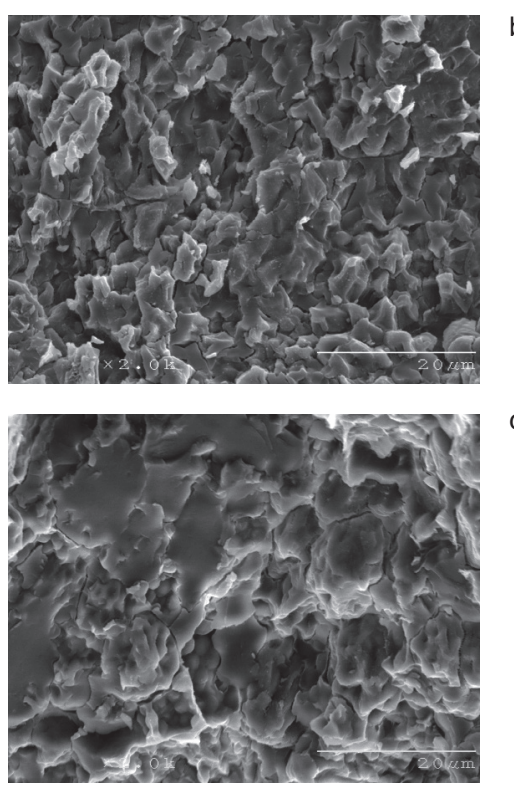

Fig. 10 The scanning electron microscope images of O-12 (a), N-12(b), and $\mathrm{K}-12$ (c). The scale bar indicates $20 \mu \mathrm{m}(\times 2000)$. 
コンシステンシーの大きな米粉ペーストが調製できることが 確認できた。 またレオロジー特性（定常流粘度やWGM パ ラメータ）は各米粉の見かけのアミロース含量と相関がある ことから米粉ペーストのレオロジー特性はアミロースの含有 率により大きく変化することがわかった，これまで米粉ペー ストの線形領域での粘弾性パラメータからその構造を推察す る試みはほとんど報告がないが，WGM を用いることで米粉 中の含まれるデンプン粒から成るコロイド濃厚分散体として の米粉ペーストのレオロジー特性の一端を定量化することが できた. Fig. 9 および Fig. 10 を比較すると, オボロツキでは 糊化によって米粉ペースト中にそのデンプン粒が分散してい る状態が観察されたが，キタミズホの米粉は糊化によっても 胚乳の構造が崩れにくく米粉ペースト中に比較的サイズの大 きなコロイド粒子が存在することがわかった。 その結果とし て米粉ペースト内のコロイド粒子の充填率が相対的に上昇し, 同一米粉濃度で比較すると高いコンシステンシーが観察され たと推察できる。一方で, Fig. 10aのオボロツキと c のキタ ミズホの画像を比較するとデンプン粒と思われる多角形（c では明確ではないが）の構造のサイズが異なるように見える ことから，アミロース含量とデンプン粒のサイズの間に何ら かの相関があるという可能性も示唆される.

このようなアミロース含量の違いによる形態の相違の原因 についてはさまざまな要因が関係すると考えられる。一つは 各品種の精白米自体の物性の違いである。精白米の力学物性 (曲げ剛性) は含水量の上昇とともに低下することが報告さ れている ${ }^{20)}$ ：これは精白米へ水が浸潤することでアミロプラ ス卜の構造が脆弱化するためであると考えられる。また一方 で米粉の糊化特性（レオロジー特性）は製粉時の吸水状態に よって変化することも報告されている ${ }^{21)}$. これらの先行研究 の結果より本研究で用いた米粉試料は, 品種により製粉操作 による力学的損傷度合いが異なることが考えられる. そして 損傷度合いによる吸湿性の違いが生じ, その結果として糊化 したペーストの状態が異なることが考えられる。

アミロース含量の違いによるデンプン糊液のレオロジー特 性の差異についてのさらなる詳細な検討を進めるためには米 粉から純粋なデンプンを抽出し, 損傷デンプン量等の重要な 特性值を得ながら本研究で行ったような構造一物性相関に関 する研究を行う必要があると考えられる。

\section{4. 結 論}

米粉ペーストのレオロジー特性における, 米粉中に存在す る米デンプンのアミロース含有量依存性について weak-gel model パラメータを用いて調べた. 高アミロース米であるキ タミズホは中アミロース米のナナツボシおよび低アミロース 米のオボロツキと比較すると低濃度で高い弾性率を示した。 米粉ペースト中に含まれる膨潤したデンプン粒の充填度を示 すと考えられる配位数 $\mathrm{z}$ の濃度依存性および米粉ペーストを 凍結乾燥した試料の走査型電子顕微鏡観察より, 米粉中の膨 潤したコロイド粒子のサイズはアミロース含量に依存するこ とが明らかになり，これが高アミロース米であるキタミズホ の米粉ペーストの特異的なレオロジー特性発現の要因の一つ であると考えられた。 しかしながらアミロース含量によるこ のような糊化ペーストのレオロジーおよび SEM 画像による 構造の相違の分子論的な原因は現時点では不明である.
今後の課題としては糊化した状態でのデンプン粒の内部の 微細構造, 特にナノスケールの構造解析が必要である. 我々 はすでに小角 X 線散乱法を用いて米粉ペーストのナノ構造 に関する研究に着手しており, 高アミロース米のデンプン粒 に特徵的な構造を持つことを観察している。 またアミロース はデンプン糊液の老化を促進すると言われているがそのメカ ニズムの詳細については不明である。この問題もレオロジー およびナノ構造解析で興味深い研究成果が得られつつあり近 い将来に論文化を予定している。

\section{謝 辞}

本研究は国立研究法人農業・食品産業技術総合研究機構北 海道農業研究センターと酪農学園大学との協定研究として行 われた。キタミズホをはじめとする各種米粉試料の提供およ びキタミズホの特性に関する情報提供を頂いた同研究セン ター作物開発研究領域水稲育種グループの皆様に感謝の意を 表します。

\section{REFERENCES}

1) Ashida K, Koya K, Umemoto T, Nippon Shokuhin Kagaku Kougaku Kaishi, 66, 290 (2019).

2) Wani AA, Singh P, Shah MA, Schweiggert-Weisz U, Gul K, Wani IA, Comprehensive Reviews in Food Science and Food Safety, 11, 417 (2012).

3) Waigh TA, Jenkins PJ, Donald AM, Faraday Discuss, 103, 325 (2001).

4) Lopez-Rubio A, Gilbert EP, Trends Food Sci Technol, 20, 576 (2009).

5) Hirose M, Ichikawa A, Nippon Shokuhin Kagaku Kougaku Kaishi, 60, 723 (2013).

6) Bohlin LA, J Colloid and Interface Sci, 74, 423 (1980).

7) Gabriele D, de Cindio B, D' Antona P, Rheol Acta, 40, 120(2001).

8) Winter HH, Chambon F, J Rheol, 30, 367 (1986).

9) Miura M, Yamauchi F, Nippon Shokuhin Kogyo Gakkaishi, 31, 783 (1984).

10) Meza BE, Chesterton AKS, Verdini RA, Rubiolo AC, Sadd PA, Moggridge GD, Wilson DI, J. Food Eng, 104, 592 (2011).

11) Meza BE , Vendini RA, Rubiolo AC, J. Food Engineering, 109, 475 (2012).

12) Roversi T, Piazza L, Eur Food Res Technol, 242, 421 (2016).

13) Nicole N, Caimeng Z, Joseph H, Eric K, Yufei H, J. Texture Studies, 47, 112 (2016).

14) Kaneda I, J Biorheology 32, 9 (2018).

15) Kaneda I, Shibata S, Nihon Reoroji Gakkaishi (Journal of the Society of Rheology, Japan), 48, 1 (2020).

16) Takahashi T, Fujita N, Food Hydrocolloids, 62, 83 (2017).

17) Yamamoto K, Shimizu H, Kurihara M, Kamata H, Nagasawa K, Funatsuki M, Yamauchi H, Bulletin of Hokkaido Food Processing Research Center, No.11, 29 (2015).

18) Hoover R, Sailaja Y, Sosulski FW, Food Res Int, 29, 99 (1996). 
19) Lindeboom N, Chang PR, Tyler RT, Starch, 56, 89 (2004).

20) Shimizu H, Sakai M, Journal of the Japanese Society of Auricularl Machinery, 36, 108 (1974).
21) Homma N, Takahashi M, Yoshii Y, Nippon Shokuhin Kagaku Kougaku Kaishi, 63, 551 (2016). 